\title{
REKONSTRUKSI TEOLOGI ISLAM KAJIAN KRITIS TERHADAP USAHA PEMBAHARUAN MENUJU TEOLOGI PRAKTIS
}

\author{
Suparman Syukur \\ Universitas Islam Negeri (UIN)Walisongo Semarang \\ e-mail: suparman_syukur@yahoo.com
}

\begin{abstract}
The terminology of various theology concepts is very basic in human life, especially when man realizes that he is a creature that have duty to submissive and obedient to God as his creator. Talking about the relationship between man and God will, so other beliefs to the prophets, angles, and another creatures should be aroused, We must prove everything of ours believing in the real life. Therefore, thestudy of theological view, alsobe associated with the functions and obligations of human beings responsible in this life. There are various concepts of belief in God, the Prophets, Angels, and another creatures, is how tobecome an habit over the years, it becomes very important to be revitalized in a more meaningful understanding of the dynamics of human daily life. Through that theological beliefs, expected to reflect the improvement of human performance and dedication in order to carry out the mandate as earth's caliph.
\end{abstract}

Abstrak: Terminologi tentang teologi dengan berbagai kosep dan teorinya merupakan hal yang sangat mendasar dalam kehidupan manusia, apalagi ketika menusia menyadari bahwa dirinya sebagai makhluk memiliki kuajiban untuk tunduk dan patuh kepada penciptanya Tuhan Yang Maha Esa. Berbicara masalah hubungan antara manusia dan Tuhan akan merefleksikan kepercayaan lain yang wajib muncul adanya, seperti kepercayaan kepada Nabi, Malaikat dan kepercayaan kepada makhluk halus lainnya. Kepercayaan kepada semuanya itu harus dibuktikan secara nyata dalam kehidupan keseharian manusia. Oleh karena itu dalam penelitian tentang pemikiran teologi, juga harus dikaitkan dengan fungsi dan kwajiban manusia yang bertanggungjawab dalam kehidupan di dunia ini. Berbagai konsep tentang kepercayaan kepada Tuhan, Nabi, Malakat dan lain sebagainya yang bersifat transendental 
sebagaimana menjadi kebiasaan selama ini, menjadi sangat penting untuk direvitalisasikan dalam pemahaman yang lebih bermakna demi kepentingan di dunia dalam dinamika keseharian manusia. Melalui pembumian keyakinan teologis itu, diharapkan mampu merefleksikan kepada peningkatan kinerja dan dedikasi manusia dalam rangka mengemban amanat kekhalifahannya di bumi ini.

Keywords: ilmukalam, khalïfah, al-yasar al-Islāmī, teologipraktis, revitalisasi Turas.

\section{A. Pendahuluan}

Berbicara masalah Teologi Islam atau yang biasa dikenal sebagai Ilmu Kalam, maka pola pikir yang hendak dibangun dalam konstruksi ideal akan sangat kompleks terkait dengan berbagai terminologi kalämiyah. Satu hal yang penting dijadikan perhatian dalam penulisan ini adalah pengertian tentang Ilmu Kalam atau Ilmu Teologi Islam itu sendiri, karena berbagai sudut pandang tentang pengertian konvensional tentang ilmu kalam sering kali terkungkung pada kesadaran yang tercakup dalam terminologi tentang ketuhanan. Pemikiran tentang "ketuhanan", kebiasaan yang akan muncul dalam benak kita adalah terkait dengan zat Tuhan, sifat, dan kekuasaan Tuhan. Oleh karena itu efek yang akan timbul dalam bentuk kesadaran manusia terhadap Tuhannya tidak lain terkait hanya dalam hal-hal yang bersifat transendental.

Keyakinan dan kepercayaan manusia terhadap Tuhan yang bersifat an sich transendental itu akan membentuk perasaan manusia yang kerdil bersifat apatis. Perasaan apatisme itu pada gilirannya akan membuat diri manusia memiliki anggapan negatif terhadap kemampuan manusia dalam mengemban dinamika kehidupannya. Padahal perlu disadari bahwa penciptaan manusia oleh Tuhan dimaksudkan agar manusia mampu menempatkan dirinya pada posisi fungsional. Artinya, penciptaan itu dimaksudkan agar manusia bersifat dinamis kritis untuk mendorong kepercayaan 
dirinya menempati posisi yang memungkinkan dirinya menjalankan fungsinya sebagai khalïfah. Perhatikan firman Allah dalam QS. alBaqarah [2]: 30 yang berbunyi innī Jāilun fi al-arḍi khalïfah (Sesungguhnya Aku hendak menjadikan seorang khalifah di muka bumi).

Pada ayat tersebut kehendak Allah itu menjadikan makhluk lain yang lebih dahulu dicipta yaitu Jin dan Malaikat keberatan atas kehendak-Nya itu. Hal itu jika ditelsuri lebih lanjut, ternyata karena manusia kelak akan dicipta dengan kesempurnaan kemampuan rasional yang bersifat dinamis, dimana hal itu tergambar dalam kelanjutan ayatnya yaitu ataj'alu fihā man yufsidu fïhā wa yasfiku aldimā'. Keberatan Malaikat dan Jin itu karena manusia hendak tercipta mampu berkreasi untuk kemakmuran dunia, sehingga dikhawatirkan akan memunculkan "kerusakan" (ifsād) dan gesekan emosional kemarahan yang mengakibatkan adanya pertumpahan darah (ifsāk). Kekhawatiran itu memang cukup beralasan, akan tetapi karena manusia tercipta di bumi ini dengan dibekali akal dan perasaan kejiwaan, maka kekhawatiran itu-meskipun tetap ada sepanjang sejarah kemanusiaan-bisadiminimalisasikan menuju titik terendah.Akibat yang akan muncul setelah itu adalah idealitas kehidupan manusia sesuai dengan yang dikehendaki, yakni untuk selalu mengabdi dan taat kepada Penciptanya. Itulah rupanya yang bisa disadari bahwa Allah selalu menghendaki hamba-Nya untuk selalu beribadah, sebagaimana firman-Nya, QS. al-Żāriyat [51]: wamā khalaqtu al-jinna wa al-insa illā liya'budūn (Dan Aku tidak menciptakan jin dan manusia melainkan supaya mereka menyembah-Ku).

Jika model pemikiran melalui deduksi al-Quran sebagai tersebut di atas terabaikan, yang muncul adalah adanya perasaan pesimistis; manusia berada sangat jauh dengan Tuhannya dan akan semakin jauh melebihi jauhnya antara bumi dan langit. Manusia saat itu hanya bisa bersikap pasrah terhadap Tuhan, karena ia merasa 
tidak memiliki kekuasaan sedikitpun dibanding dengan kekuasaan Tuhan. Kenyataan ini, jika dikaitkan dengan tuntutan kehidupan kontemporer yang bersifat kompetitif, maka dasar, arah, dan sumber keilmuan teologi harus mengalami rekonstruksiepistemologinya. Rekontruksi epistemologi dimaksud, pada gilirannya akan mengarahkan pemahaman terhadap teologi secara praktis. Artinya, keyakinan teologis harus bermanfaat dan terbukti dalam kehidupan nyata.

Menurut John Swinton, teologi praktis sangat erat terkait dengan berbagai pengalaman dan dinamika kemanusiaan yang cukup kompleks. Melalui konsep teologi praktis kehidupan religiositas itu akan bersinggungan menyatu dengan segala pengetahuan manusia dalam kehidupan, ia diibaratkan sebuah tenunan yang saling terikat ujung benang satu dengan ujung benang lainnya. Di dalam pendahuluan bukunya, Swinton kemudian menegaskan, bahwa dalam perkembangan kotemporer, masalah teologi harus diantisipasi secara cermat dan ketat, karena akan menyangkut dengan segala praktek kehidupan. Di dalam agama Nasrani, peranan gereja sangat besar dalam usahanya untuk mengembangkan pemahaman dan aplikasi refleksi teologi dalam segala bentuk perilaku manusia. ${ }^{1}$

Tidak jauh berbeda, di dunia Islam terutama di Indonesia, masalah perkembangan pemahaman teologi telah dimulai meskipun masih dalam bentuk permulaan. Ahmad Jainuri, misalnya, dalam disertasinya yang berjudul "The Formation of the Muhammadiyah's Ideology 1912-1942" (1997), yang diterbitkan dalam bahasa Indonesia dengan judul Ideologi Kaum Reformis: Melacak Pandangan Keagamaan Muhammadiyah Periode Awal (2002), mencoba menawarkan sudut pandang baru tentang doktrin teologis gerakan keagamaan sebagai suatu sarana untuk membangkitkan semangat sosial kepada para pendukungnya. ${ }^{2}$ 
Hasan Hanafi adalah salah satu ilmuwan dari Mesir ikut ambil dalam mempelopori untuk menata ulang bangunan epistemologi Teologi Islam sebagaimana dimaksud. Melalui proyeknya itu, Hassan Hanafi menyerukan pentingnya "teologi pembebasan" dan transformasi, yang terejawantahkan lewat mega proyeknya al-Yasar alIslāmī, Revitalisasi Turaś hingga oksidentalisme, yang lahir sebagai refleksi dari kekacauan suasana sosial-politik dan intelektual di dunia Arab pada saat itu, yang sangat penting untuk dikaji. Konsepnya dalam bidang teologi Islam adalah bagaimana teologi itu bisa ditarik ke bumi. Dengan proyek pembumian Teologi Islam itu, diharapkan dapat menarik keyakinan yang membumbung tinggi itu bisa membumi. Dengan demikian, sumber teologi itu tidak hanya berasal dari keyakinan tentang Tuhan, tetapi juga bagaimana kehidupan di alam semesta ini juga mendapat perhatian secara teologis pula, sehingga akan tercapai imanensi ketuhanan. ${ }^{3}$

\section{B. Definisi Inovatif Teologi Islam}

Abū al-Wafā al-Ghanīmī al-Taftazāni dalam bukunya Dirāsāt fi al-Falsafah al-Islāmiyah menyatakan, bahwa Ilmu Kalam yang dikenal juga sebagai Ilmu Teologi Islam, adalah salah satu ilmu Syariah yang rasionalistis yang meliputi pokok-pokok akidah Islam yang berperan untuk mempertahankan dari berbagai pandangan dan ideologi lain yang berbeda. ${ }^{4}$ Ibn Khaldūn mendefinisikan Ilmu Kalam sebagai ilmu yang berisi tentang berbagai argumen teologis untuk mempertahankan akidah dan keimanan dengan menggunakan dalil rasional. Ia bersisi berbagai bantahan terhadap berbagai ideologi yang dianggapnya menyimpang dari keyakinan mazhab Salaf dan Ahlu al-Sunnah, sedangkan inti ajaraan dan pembahasannya tidak lain adalah tauhid.Sedangkan ahli Sejarah seperti T. J. De Boer menyatakan bahwa Teologi adalah suatu ilmu yang membahas, khususnya dalam bidang akidah Islamiyah dengan metode dialektis. ${ }^{5}$ Berbeda dengan para ahli sebelumnya, A. Hanafi menyatakan bahwa ilmu Kalam adalah sama dengan ilmu Teologi 
Islam, yang keduanya berarti ilmu Tauhid, yakni ilmu tentang hal-hal yang terkait dengan Ketuhanan. Persoalanutama yang menjadi pembahasannya adalah tentang zat Tuhan dalam segala aspek derivatifnya yang berhubungan dengan kehidupan di alam semesta ini. ${ }^{6}$

Muhammad Abduh dalam karya monumentalnya Risālah Tauhīd mengemukakan bahwa Ilmu Kalam yang juga disebut sebagai ilmu Tauhid main core-nya adalah penetapan sebuah keyakinan yang kemudian dielaborasikan dalam bentuk ajaran yang dibawa oleh para Nabi terutama Nabi Muhammad s.a.w. ${ }^{7}$ Definisi itu, jika diperhatikan secara saksama menunjukkkan adanya lobang yang bisa dimasuki jarum pengembangan dan pembaharuan, dimana Abduh mengaitkan ajaran tentang ketuhanan itu melalui penjabaran sunnah-sunnah Nabi yang terkait dengan kehidupan keseharian manusia. Lubang jarum itu kemudian bisa diperluas menjadi pintu masuk pemahaman baru yang lebih menitik beratkan pada adanya keterkaitan antara keyakinan tentang ketuhanan dengan hal-hal yang maujūd dalam alam semesta. Ilmu Kalam, yang awal mulanya berkaitan erat dengan segala unsur tentang ketuhanan, kini diperlebar menyangkut juga dinamika kehidupan di alam semesta. Dinamika kehidupan manusia apapun yang dilakukan ketika masih hidup di dunia tidak lain merupakan refleksi keyakinan teologis, baik keyakinan yang bersifat positif terkait dengan amal saleh, maupun yang negatif terkait dengan amal mungkar. Di sinilah kemudian nampak bahwa dalam menjalankan kehidupan saat ini, seseorang mesti mengukur tindakan apa yang akan dilakukan, sehingga ia memahami tentang praktek-praktek kehidupan yang bersifat teologis. Dengan demikian untuk lebih jelas mengarah kepada keinginan melakukan praktek-praktek teologis, perlu disajikan pengertian tentang praktical theology yang ditampilkan John Swinton kaitannya dengan keyakinan gerejani sebagai berikut:

Practical Theology is critical, theological reflection on the practices of the Church as they interact with the practices of the 
world, with a view to ensuring and enabling faithful participation in God's redemptive practices in, to and for the world. ${ }^{8}$

Teologi Praktis adalah teologi yang kritis, yaitu refleksi teologis terhadap berbagai dinamika yang dipraktekkan di Gereja dalam rangka pengejawantahan segala praktek kehidupan di dunia ini, dengan didasari pandangan tentang keyakinan dan kepercayaan dalam partisipasi menjalankan perintah Tuhan di dunia ini.

Memperhatikan kutipan di atas, hal yang kemudian menjadi lebih jelas adalah mengembalikan arah dan tujuan teologi kearah pengembangan suatu ilmu yang bisa dipahami secara rasional yang dilandasi dengan keyakinan teologis untuk pegabdian kepada Tuhan. Bentuk kesatuan pemahaman teologis dengan praktek-praktek kehidupan menjadi lebih jelas jika seorang muslim mampu memahami konsep fikih yang ditawarkan oleh Imam Hanafi. Kitab alFiqh al-Akbar, yakni kitab Fikih yang isinya mencakup dua sisi kepercayaan keagamaan dan dinamika kehidupan.

\section{Rekonstruksi Epistemologi dan Pemahaman Teologi Islam}

Kerangka konseptual yang perlu dipahami lebih lanjut adalah tentang komunikasi keilmuan yang dilakukan Nabi Adam, di mana ia ditugaskan Allah untuk memberitahu nama-nama sesuatu yang terkait dengan instrumen yang akan dipakai kelak oleh manusia dalam kehidupannya di bumi (QS. al-Baqarah [2]: 31). Kejadian yang bersifat sangat teologis itu, menurut hemat Din Syamsuddin terlebih dahulu diawali dengan mutual comunication antara Tuhan, Malaikat, Jin, dan Munusia, sebagaimana telah diterangkan sebelumnya. Dalam QS. al-Baqarah [2]: 30, menurutnya bahwa peradaban manusia (yang juga sebagai peradaban dinamis teologis) sangat ditentukan oleh sebuah dialog vertical spiral. Maksudnya adalah bahwa manusia mempunyai kesempatan melalui kekuatan akal dan kejiwaannya untuk mengkomunikasikan dinamika kehidupannya dengan Tuhan, manusia dan lainnya, yang bersifat exchange. ${ }^{9}$ 
Interaksi antar dan saling terkait sebagaimana disebut diatas, berlangsung secara vertikal dan spiral. Artinya ketika informasi ketuhanan itu diterima oleh manusia, maka kemudian penerimanya itu mengembangkan dan mengomunikasikannya kembali kepada pihak lain dan mengembangkan lagi. Keyakinan teologis dengan demkian dapat melahirkan dinamika kehidupan yang berupa pengembangan peradaban. Kerangka teologis yang merupakan kesatuan poros vertikal dapat merefleksikan keyakinan yang berasal dari Yang Absolut itu menjadi arah kehidupan melalui lingkaran spiral. Kerangka pemikiran yang terlahir dari interaksi dinamika antar manusia dan alam sekitarnya akan menyatu dengan kerangka pemikiran yang berasal dari keyakinan teologis melalui batang vertikalnya. Kedua kerangka pemikiran itu kelak menyatu pada suatu keyakinan terhadap yang Absolut yaitu Allah Yang Transenden dan Maha Kuasa.

Keyakinan terhadap yang Absolut itu merupakan final dari perasaan teologis dalam beragama. Perjalaan keyakinan itu, menurut Huston Smith berawal dari adanya perasaan teologis terhadap adanya "otoritas" Tuhan. Perasan kejiwaan yang optimal terhadap otoritas tersebut mengimplikasikan adanya pelaksanaan ( $t a$ 'abbud) melalui tradisi/amaliyah keagamaan. Faktor teologis selanjutnya adalah adanya unsur "spekulatif" kepasrahan kepada ketentuan Ilahi melalui keyakinan teologis adanya "kerahmatan" Tuhan. Sedangkan faktor akhir yang dapat menentukan kepasrahan seseorang adalah adanya faktor keyakinan teologis yang "misteri" dan sulit untuk dijangkau oleh nalar pikiran. Demikian itulah gambaran perjalanan keyakinan teologis yang umum terjadi pada setiap orang yang beragama. Kenyataan teologis yang dapat ditarik kesimpulan secara umum dari perjalanan teologis itu adalah timbulnya "spekulatiffatalisme" pada mayoritas pengant agama. Itulah sebabnya mengapa pada kehidupan modern yang penuh hiruk-pikuk sekarang ini diperlukan "rekonstruksi" terhadap epistemologi teologi yang baru. ${ }^{10}$ 
Konstruksi epistemologis yang muncul dari kesatuan dua sisi sumber keyakinan terhadap kekuasaan Yang Absolut sebagai mana digambarkan sebelumnya menjadi konsep baru. Melalui kontruksi epistemologi yang baru itu seseorang ahli pikir yang beriman, mampu menarik bentuk keyakinan yang transendental itu menjadi gerakan amaliyah dinamis yang reil dalam kehidupan manusia setiap harinya. Dengan demikian konsep itu akan mengarahkan keyakinan manusia terhadap Allah yang selama ini bersifat transendental menjadi keyakinan kepaNya yang bersifat Imanen. Allah menjadi dekat, selalu berada disisi manusia dan membangtunya untuk menjalankan kehidupannya di dunia secara dinamis. Bentuk keyakinan yang terungkap adalah "Allah itu lebih dekat dari urat nadi manusia", dilain pihak jga muncul suatu keyakinan bahwa Allah yang transendental itu selalu standby berada disisi manusia yang menghendakiNya. Terkait dengan hal tersebut Allah telah berfirman dalam surat Ali Imran [3]: 2 (Allāhu lā ilāha illā huwa al-ḥayyu alqayyūm). Artinya Allah selalu berada disisi manusia untuk memberi motivasi dan membantu memberi pertolongan ketika manusia menginkan melakukan sesuatu yang positif. Konsep epistemologi baru ini dapat mengindikasikan bahwa dimanapun manusia berada ia harus memiliki kemauan positif untuk mengimplimentasikan ta'abud-nya kepada Allah. Demikianlah akhirnya kita tidak terlalu sulit untuk memahami statement ilahiyah yang berbunyi: wa mā khalaqtu al-jinna wa al-insa illā liya'budūn (QS. al-Żāriyāt [50]: 56).

Rekonstruksi epistemologi Teologi Islam, sebagaimana telah diuraikan diatas, dalam dataran praktek, menurut Tobroni ${ }^{11}$ lebih mendasar disebut sebagai "Rekontruksi Filosofis Ontologis" melalui empat tahap perubahan pemahaman teologis yang mendasar. Pemahaman tentang konsep Tuhan: dari al-Ilāh ke al-Rab; Pandangan tentang Nabi: dari al-ma'sum ke al-uswah; Pandangan tentang manusia ideal: dari al-makluq ke khalïfah Allāh; dan Pandangan tentang dunia: dari mistisisme ${ }^{12}$ ke asketisme ${ }^{13}$. 
Hal itu terjadi, pertama pada penekanan pengembangan konsep dari keyakinan kepada Allah sebagai al-Ilāh menjadi al-Rabb. Artinya, mainstreampemikiran keagamaan yang selama ini bercorak tosentris (berpusat pada Tuhan) yang menjadikan agama sebagai petunjuk teknis untuk melayani Tuhan secara vertikal antara "tersembah dan penyembah", menjadi "spiral-horizontal dan vertikal". Dalam hal ini hubungan manusia dengan Tuhannya tidak lagi bersifat apatis (yakni pengakuan atas transendensi dan kemahakuasaan Tuhan atas segala sesuatu), akan tetapi menjadi bersifat dinamis (yakni pengakuan atas transendensi dan kemahakuasaan Tuhan atas segala sesuatu itu dapat merefleksikan adanya kerahmatan Tuhan yang selalu bersama manusia sebagai khalifah-Nya).

Konsep pragmatisnya adalah, bahwa term al-Ilāh yang memiliki pegertian Allah sebagai Tuhan yang maha kuasa dan tak terjangkau, yang misteri, dan maha tinggi merupakan gambaran tentang subtantif Tuhan. Sedangkan term Rabb, adalah gambaran Allah yang berfirman, berbuat, mengayomi, mencipta, memelihara, memberi rezeki, dan lain sebagainya yang bersifat andragogis. Sekalipun kata "Allah" terdapat lebih dari 2500 kali dalam al-Quran, disamping ungkapan tentang Rabb, Raḥmān, al-Raḥimm, dan lain-lain. Kitab Suci al-Quran bukanlah wacana tentang Tuhan dan sifat-sifatNya. Eksistensi Tuhan dalam al-Quran bersifat fungsional: Dia Pencipta, Pemelihara alam dan manusia, dan khususnya Pemberi petunjuk kepada manusia melalui wahyu-Nya. Ia juga sekaligus yang mengadili manusia, baik secara individual maupun kolektif, melalui mahkamah keadilan yang diliputi kasih sayang. ${ }^{14}$

Melalui konsep teologis yang membumi seperti itu, diharapkan manusia dalam menjalankan segala kewajiban hidupnya, tidak lagi mengukur amaliyah itu dengan akibat final "surga-neraka", tetapi lebih mengacu kepada penerimaan fungsi sebagai khalïfah yang memiliki kesadaran atas tanggungjawabnya kepada Pencipta. Hal itu 
nampaknya dapat dengan mudah dipahami sebagai beramal "tanpa pamrih" (lii'lā'i kalimatillāh), yang hasilnya tentu lebih valid dan berkualitas.

Hal kedua, adalah reformulasi pandangan tentang Nabi, dimana pandangan terhadapnya sebagai yang ma'șūm menuju pandangan terhadapnya sebagai uswah. Menurut Tobroni, bahwa sebagian umat Islam memandang berlebihan kepada Nabi Muhammad, di mana ia dipandang sebagai setengah dewa bahkan dianggap setingkat dibawah Tuhan. Keyakinan yang berlebihan bahwa Nabi sebagai yang ma’sūm memiliki hak memberi syafaat ketika di hari kiamat perlu ditinjau ulang menuju yang lebih realistis membumi. Kultuisme yang begitu tinggi kepadanya menjadi lebih mengakar dalam keyakinan teologis masyarakat Islam, ketika dilengkapi dengan keyakinan tentang "Nur Muhammad" sebagai cikal bakal segala kehidupan ${ }^{15}$. Pandangan seperti itu perlu mendapat perhatian lebih lanjut dengan penafsiran seperlunya agar masyarakat Islam tidak terjebak pada bayangan yang utopis. Nabi Muhammad sebagai Nabi akhir zaman merupakan rahmat bagi alam semesta. Artinya, dia sebagai panutan yang diberi tanggungjawab oleh Allah untuk memberi suri tauladan dalam berbagai amalan religius, dengan demikian sifat dan perilaku kenabiannya itu menjadi top model yang harus diteladani. ${ }^{16}$

Menyadari tetang sifat dan kedudukan Muhammad sebagai Nabi dan Rasul, maka umat Islam perlu menyadari bahwa yang harus dipahami lebih lanjut adalah sisi kemanusiaan yang menyatu dengan sisi kerasulannya, Allah berfirman dalam QS. al-Kahfi [18]: 110, sebagai berikut:

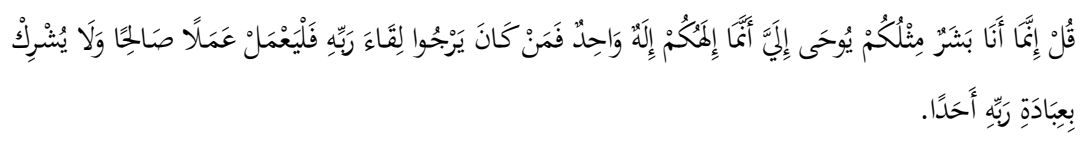

Katakanlah: "Sesungguhnya aku ini hanya seorang manusia seperti kamu, yang diwahyukan kepadaku: "Bahwa sesungguh- 
nya Tuhan kamu itu adalah Tuhan Yang Esa". Barang siapa mengharap perjumpaan dengan Tuhannya maka hendaklah ia mengerjakan amal yang saleh dan janganlah ia mempersekutukan seorang pun dalam beribadah kepada Tuhannya."

Memperhatikan firman Allah tersebut, terdapat ungkapan innamā yang dikenal sebagai al-hasr yang menunjukkan adanya makna pengkhususan dengan kata "hanya" yang maknanya bahwa Muhammad tidak lain adalah sebagai "manusia" biasa. Ia sebagai Nabi dibedakan dari manusia lainnya dengan adanya penghormatan dengan diberi wahyu. ${ }^{17}$ Pernyataan Nabi dengan kata "qul innamā ana basyarun" menunjukkan adanya harapan dengan penuh permisif agar umatnya mengerti bahwa yang harus dihormati adalah eksistensi wahyu. Kewahyuan itu menurut Sami' 'Ațif al-Zin ditampilkan untuk menghadapi adanya ejekan dari kaum kafir, agar mereka mau mengerti tentang kelebihan wahyu yang tidak terbatas keilmuan Allah itu. Dengan demikian jelaslah bahwa pandangan teologis tentang eskatologi Nabi Muhammad s.a.w. adalah melekatnya kewahyuan pada diri Nabi. Maka implementasi penghormatan kepada Nabi adalah terletak pada sejauh mana umat Islam meneladani sunnah dan melaksanakan segala perintahnya dengan penuh keikhlasan. ${ }^{18}$

Pandangan teologis terhadap realitas kehidupan di dunia ini perlu diperbaharui menuju yang lebih sempurna, yakni dari pemahaman terhadap dunia yang mistis ini menuju pemahan yang lebih sempurna dengan menyadari adanya unsur pemahaman "utilitarianisme"19. Artinya, bahwa kehidupan duniawi dengan segala dinamikanya itu diusahakan dapat mencapai manfaat yang maksimal melalui perjuangan yang disebut jihād. Alam diciptakan untuk kepentingan manusia sebagai sarana mutlak bagi pelaksanaan misi kekhalifahannya di bumi. Perhatikan firman Allah: Dan Dia menundukkan untukmu apa yang ada di langit dan apa yang ada di bumi semuanya, (sebagai rahmat) daripada-Nya. Sesungguhnya pada 
yang demikian itu benar-benar terdapat tanda-tanda (kekuasaan Allah) bagi kaum yang berpikir (QS. al-Jasiiyah [45]: 13).

Pandangan tentang alam sebagai fasilitas bagi kehidupan manusia, tentunya harus ditindaklanjuti dengan semangat jihad untuk mengemban amanat demi mencapai kebermanfaatan kehidupan di dunia ini. Pandangan yang bersifat asketis ini selaras dengan pandangan Tobroni yang merujuk pada pandangan Webber bahwa dunia ini adalah realitas, dan intensifikasi pengabdian agama yang dijalankan dalam kegairahan kerja sebagai gambaran dan pernyataan dari manusia terpilih. Jalan keselamatan dicari tidak dengan meninggalkan atau membelakangi dunia, tetapi dengan menundukkannya. ${ }^{20} \mathrm{Hal}$ itu, menurut hemat Tobroni selaras dengan pandangan Qurani, surat al-Baqarah [2]: 269, sebagai berikut:

Allah menganugerahkan al-hikmah (kepahaman yang dalam tentang al-Quran dan al-Sunnah) kepada siapa yang Dia kehendaki. Dan barang siapa yang dianugerahi al-hikmahitu, ia benar-benar telah dianugerahi karunia yang banyak. Dan hanya orang-orang yang berakallah yang dapat mengambil pelajaran (dari firman Allah).

Ayat itu jika ditelusuri lebih lanjut akan terungkap adanya korelasi positif antara peran akal dengan perilaku kebenaran yang bersifat teologis. Quraish Shihab menyatakanbahwa sesungguhnya berbahagia lagi bijaksana yang mengetahui dan menerapkan yang baik dan benar. Menurutnya, akal sehat menetapkan bahwa jalan yang baik dan benar adalah jalan Allah. Oleh karena itu siapa saja yang menelusurinya mendapat ketentraman serta meraih peningkatan. Itulah pilihan yang bijaksana, sayang tidak semua orang menelusurinya. Memang hanya yang dianugerahi hikmah ${ }^{21}$ yang dapat memahami dan mengambil pilihan yang tepat. Oleh karena itu Allah memerintahkan Luqmān al-Hāakim untuk mensyukuri nikmatNya itu, karena dengan pemberian hikmah itu seseorang dapat melakukan segala dinamika kehidupan dengan baik dan benar, tetapi 
jika mengabaikannya, Allah memperingatkannya dengan keras (QS. Luqmān [31]:12) sebagai berikut:

Dan sesungguhnya telah Kami berikan hikmah kepada Lukman, yaitu: "Bersyukurlah kepada Allah. Dan barang siapa yang bersyukur (kepada Allah), maka sesungguhnya ia bersyukur untuk dirinya sendiri; dan barang siapa yang tidak bersyukur, maka sesungguhnya Allah Maha Kaya lagi Maha Terpuji".

Dalam pembicaraan di atas, sekalipun tekanannya tentang Tuhan, persoalan manusia telah banyak disinggung. Hal itu dapat di lihat, bahwa tema pokok al-Quran sebenarnya adalah tentang manusia dan masalah yang dihadapinya dalam kehidupan. Bila ditengok secara fisik, manusia tidak banyak berbeda dengan makhluk yang lain, tetapi dari segi ruhani perbedaan itu sangat jelas, karena Tuhan "meniup ruh-Nya sendiri" kepada bangunan asal kejadian manusia itu. Hal itulah yang menyebabkan kemudian manusia dipercayai untuk memikul amanah berupa tugas menciptakan tata kehidupan yang bermoral di muka bumi ini. Al-Quran menyebutkan, Sesungguhnya Kami telah mengemukakan amanat kepada langit, bumi dan gunung-gunung, maka semuanya enggan untuk memikul amanat itu dan mereka khawatir akan mengkhianatinya, dan dipikullah amanat itu oleh manusia. Sesungguhnya manusia itu amat lalim dan amat bodoh (QS. al-Ahzab [33]: 72). Hal itu karena manusia enggan melaksanakan perintahNya, Allah berfirman, Sekali-kali jangan; manusia itu belum melaksanakan apa yang diperintahkan Allah kepadanya. (QS. 'Abasa [80]: 23).

Begitulah pandangan yang seharusnya terhadap realitas manusia yang memiliki tugas ke-khalïfah-an di bumi ini. Bagi yang mengingkari realitas itu akan bersikap apatis dan bersifat fatalis yang pada gilirannya menjadi pemalas dan ia berarti mati sakjeroning urip. Hal yang perlu diantisipasi dengan kenyataan itu adalah melawan sekeras mungkin sikap negatif itu, karena sikap yang timbul dari dirinya sendiri itu tidak lain adalah Jin dan syetan yang terktuk. Oleh 
karena itu, dalam rangka merekontruksi pandangan teologis terhadap eksistensi makhluk yang jahat itu tidak lain adalah "sifat negatif yang ada dalam diri manusia sendiri". Di dalam diri manusia ada dua potensi yang saling mempengaruhi perilaku manusia, yakni al-fujūr (sikap negaitif kefasikan dan al-taqwā sifat positif ketakwaan) ${ }^{22}$. Jin dan setan, ${ }^{23}$ sebagaimana dipercayai adanya yang menurut Abdul Khaleed Ibn Ibraaheem Ameen ia adalah sesuatu yang tersembunyi dan selalu menyeliap pada diri seseorang, jadi tidak berada jauh di luar. Maka seorang yang salih harus selalu menyingkirkannya agar tidak mengganggu manusia dalam usahanya menjalankan perintah Allah dan sunnah Nabi-Nya. ${ }^{24}$

\section{Penutup}

Pada sisi akhir artikel ini, dapat disadari bahwa kehidupan religius tidak lain adalah bagaimana seorang muslim mampu menggabungkan dan mengaitkan secara simbiosis antara kewajiban manusia untuk beriman, beribadah (ta'abbud), dan pada akhirnya merefleksikan dalam dinamika kehidupan. Hal itu selaras dengan pandangan tentang al-Quran, dimana pada hakikatnya kitab itu berisi tentang dokumen keagamaan dan etika yang bertujuan praktis menciptakan masyarakat yang bermoral, baik, dan adil. Artinya, bahwa manusia tercipta di bumi ini sepantasnya ia berbuat sesuai pesan-pesan religiusitas Ilahi, yang dipadukan dengan akal, dan emosi kemanusiaan yang sehat.

Menyadari tentang posisi manusia sebagai makhluk yang mengemban unsur dan amanat ke-khalïfah-an, maka sudah barang tentu tuntutan yang harus dipenuhi adalah bagaimana mereka berusaha menjadikan dirinya dan orang lain sebagai insan-insan saleh religius. Kesalehan dan sifat religiusitasnya itu harus dipraktekkan dalam bentuk perilaku sesuai dengan keyakinan teologis yang membumi terkait dengan segala dinamika kehidupan. Keyakinan teologis sebagaimana telah digambarkan, dapat menjadikan manusia 
sadar dan peka serta meyakini adanya satu Tuhan yang memerintahkan kebaikan dan melarang kejahatan. Konsekuensinya, menurut Fazlur Rahman, bahwa teori dan konsep teologis yang harus dipahami adalah adanya kesadaran bahwa al-Quran tidak terlalu banyak menyinggung tentang teori Ketuhanan, akan tetapi seruan-seruannya dapat merefleksikan adanya keluasan dan keteraturan alam semesta. ${ }^{25}$ Argumen mendasar ini kiranya dapat dipakai tidak untuk meneguhkan eksistensi teoritis Tuhan, tetapi adalah untuk melukiskan keagunganNya yang hidup dan keindahanNya yang penuh tujuan. Oleh karena itu penekanan alQuran terkait dengan dinamika teologis, adalah pada sisi keimanan yang dibuktikan dalam tindakan.[]

\section{Catatan Akhir}

1John Swinton and Harriet Mowat, Practical Theology and Qualitative Research, London: SCM Press, 2006, h. 3.

2Fauzan Saleh, Teologi Pembaharuan: Pergeseran Wacana Islam

Sunni di Indonesia Abad XX, Jakarta: Serambi, 2000, h. 31.

${ }^{3}$ http://fathirhabibie.blogspot.com/2011/03

${ }^{4} \mathrm{Abū}$ al-Wafā al-Ghanimi al-Taftazāni, Dirāsāt fĩ al-Falsafah alIslāmiyah, Kairo: Maktab al-Qāhirah al-Ḥadīsah, I, 1957, h. 3.

5T. J. De Boer, T.J., dalam Muhammad Abdul Hadi Abu Raidah, Tārīkh al-Falsafah al-Islämiyah, Mesir: Lajnah al-Ta'līf wa al-Tarjamah wa al-Nasyr, 1938, h. 51.

${ }^{6}$ A. Hanafi, Theologi Islam, Jakarta: Bulan Bintang, 1979, h. 5.

7Muhammad Abduh, Risalah Tauhid, Jakarta: Bulan Bintang, 1979, h. 37.

8John Swinton dan Harriet Mowat, Practical Theology, h. 6.

'DinSyamsuddin,"Information Minded", dalam Suara

Muhammadiyah, No. 06 TH Ke 99, 16-31 Maret 2014, h. 27.

${ }^{10}$ HustonSmith, Agama-Agama Manusia, terj. Safroedin Bahar, Jakarta: Yayasan Obor, 2001, h. 120.

11Tobroni, "Rekontruksi Pembelajaran AIK di PTM" dalam Suara

Muhammadiyah, No. 06 TH Ke 99, 16-31 Maret 2014, h. 48.

12Mistisisme adalah bentuk keyakinan yang bersikap mistis, menurut Munir Baalbaki (Munir Baalbaki, al-Mawrid: A Modern 
English-Arabic Dictionary, Beirut: Dar El Ilm Lil-Malayen, 1974, h. 602), dapat digambarkan sebagai berikut:

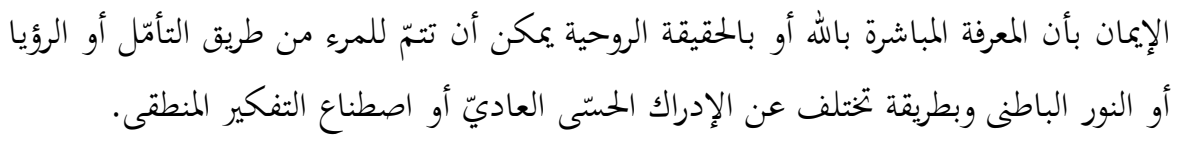

${ }^{13}$ Asketisme adalah bentuk pemahaman yang menunjukkan adanya usaha untuk mempraktikkan kesederhanaan, kejujuran, dan kerelaan berkorban. (Hasan Alwi, red. 2002: 71)

${ }^{14}$ Ahmad Syafii Maarif, Membumikan Islam, Yogyakarta: Pustaka Pelajar, 1995, h. 4.

15Keyakinan ini adalah akidah Sufiyah, dimana orang-orang Sufi beranggapan bahwa semua yang ada di alam semesta ini diciptakan dari nur (cahaya) Muhammad kemudian bertebaran di alam semesta. Keyakinan ini merupakan ciri khas dari kelompok Sufiyah, keyakinan mereka ini tercantum dalam kitab Majmū'ah Mawlid Syaraf al-Anāam wa Ad'iyatuh. Naskah Arabnya tertulis: وأصلى وأسم على النور الموصوف بالتقدم . Kaum sufi mengemukakan pandangannya tentang munculnya alam semesta dari Tuhan Yang Maha Esa melalui "Nūr Muhammad" (alhaqīqah al-Muhammadiyah). Nabi Muhammad diyakini memiliki dua esensi, ia sebagai nur yang azali dan bersifat qadim yang menjadi sumber segala sesuatu, sedangkan disisi lain ia sebagai yang baru dan terbatas oleh ruang dan waktu. Menurut Manșūr al-Ḥallāj, wujudnya mendahului 'adam (ketiadaan), dan namanya melampui qalām, karena ia telah ada sebelum lainnnya ada (Baca al-Hallaj, Tawasin: Kitab Kematian, terj. Muhammad al-Fayyadl, Yogyakarta: Pustaka Sufi, 2002, h. 5).

16Tobroni, "Rekonstruksi Pembelajaran", h. 49.

17Muhammad 'Ali al-Ṣabūnī, Ṣafwat al-Tafasīr, Beirut: Dār alQur'ān al-Karīm, 1981, h. 32.

18Sāmi' 'Ātif al-Zain, Mu'jam al-Amśāl fì al-Qur'ān al-Karīm, alQāhirah: Dār al-Kitāb al-Mișri, 2000, h. 138.

19Utilitarianisme berasal dari bahasa Inggris "utilitarianism", dijabarkan dari bahasa Latin "utilis", yang berarti bermanfaat. Utilis mengatakan bahwa ciri pengenal kesusilaan ialah manfaat suatu perbuatan. Suatu perbuatan dikatakan baik jika membawa manfaat, dikatakan buruk jika menimbulkan mudarat. Senada dengan pendapat Suhrawardi, "utilis" dapat 
diartikan sebagai hal yang berguna/bermanfaat. Dalam aliran atau faham ini ukuran baik atau buruk didasarkan kepada : "Apakah perbuatan tersebut berguna atau bermanfaat." Apabila perbuatan tersebut bermanfaat atau berguna, maka (perbuatan tersebutlah) yang dipandang sebagai perbuatan baik. Sebaliknya apabila perbuatan tersebut tidak bermanfaat atau tidak berguna, maka perbuatan tersebut dipandang sebagai perbuatan yang buruk. Menurut Smart, bahwa "Utilitarianism can be described as the doctrine which states tha the rightness or wrongness of action is determined by the goodness and badness of their consequences."(J. J. Smart, "Utilitarianism", dalam Paul Edwards (editor in chief), The Encyclopedia of Philosophy, Vol. VII, New York, 1967, h. 206).

20Tobroni, "Rekonstruksi Pembelajaran", h. 49.

${ }^{21}$ Hikmah terambil dari kata "hakama" yang pada mulanya berarti "menghalangi". Bermula dari kata yang sama kemudian dibentuklah kata yang bermakna "kendali", yakni sesuatu yang fungsinya mengantar kepada yang baik dan menghindarkan dari yang buruk. Untuk mencapai maksud tersebut diperlukan pengetahuan dan kemampuan menerapkannya; M. Quraish Shihab, Menyingkap Tabir Ilahi: Asma al-Husna dalam Perspektif al-Qur'an, Jakarta: LenteraHati, 1998, h. 144-145.

فَأَلْمَهَها فُجُورَهَا وَتَقْوَاهَا

${ }^{23}$ The word jinn in Arabic refers to something that is concealed and hidden. Al-Jān is the father of the jinn, the plural of which is Jinān. It says in Lisān al-'Arab: Janana means to cover or conceal. Everything that is concealed from you is Junna 'Anka (concealed from you). Jannahu al-Layl means the night covered him. The Jinn are so called because they are concealed and hidden from view. Hence the foetus is called al-Janin because he is concealed in his mother's womb; lihat: Abdul Khaleed Ibn IbraaheemAmeen, The Jinn and Human Sickness: Remedies in the Light of the Qur'an \&Sunnah, Riyaḍ: Dār al-Salām, 2005, h. 31; juga Ibn al-Manżūr, Lisān al-'Arab, al-Qāhirah, Dār al-Hadīis, 2002.

${ }^{24}$ Abdul Khaleed Ibn IbraaheemAmeen, The Jinn and Human Sickness, h. 31.

25Fazlur Rahman, Islam, terj. Ahsin Muhammad, Bandung: Penerbit Pustaka, 1984, h. 116. 


\section{DAFTAR PUSTAKA}

Abduh, Muhammad, Risalah Tauhid, Jakarta: Bulan Bintang, 1979.

Alwi, Hasan, (Pimpinan Redaksi), Kamus Besar Bahasa Indonesia, Jakarta: Balai Pustaka, Edisi Ketiga, 2002.

Zain, Sāmi' 'Āṭif, Mu'jam al-Amśāl fi al-Qur'ān al-Karīm, al-Qāhirah: Dār al-Kitāb al-Mișri, 2000.

Ameen, Abdul Khaleed Ibn Ibraaheem,The Jinn and Human Sickness: Remedies in the Light of the Qur'an \&Sunnah, Riyaḍ: Dār alSalām, 2005.

Baalbaki,Munir, al-Mawrid: A Modern English-Arabic Dictionary, Beirut: Dar El Ilm Lil-Malayen, 1974.

De Boer, T.J., dalam Muhammad Abd al-Hādī Abū Raidah, Tārīkh alFalsafah al-Islāmiyah, Mesir: Lajnatu al-Ta'līf wa al-Tarjamah wa al-Nasyr, 1938.

Hallaj, Tawasin: Kitab Kematian, terj. Muhammad al-Fayyadl, Yogyakarta: Pustaka Sufi, 2002.

Hanafi, A., Theologi Islam, Jakarta: Bulan Bintang, 1979.

http://fathirhabibie.blogspot.com/2011/03

Maarif, Ahmad Syafii, Membumikan Islam, Yogyakarta: Pustaka Pelajar, 1995.

Rahman, Fazlur, Islam, terj. Ahsin Muhammad, Bandung: Penerbit Pustaka, 1984.

Șabūnī, Muhạmmad Ali, Șafwat al-Tafasīr, Beirut: Dār al-Qur'ān alKarīm, 1981.

Saleh, Fauzan, Teologi Pembaharuan: Pergeseran Wacana Islam Sunni di Indonesia Abad XX, Jakarta, Serambi, 2000.

Shihab, M. Quraish, MenyingkapTabirIlahi; Asma al-Husna dalam Perspektif al-Qur'an, Jakarta: LenteraHati, 1998.

Smart, J.J., "Utilitarianism”, dalam Paul Edwards (editor in chief), The Encyclopedia of Philosophy, Vol. VII, New York, 1967. 
PETUNJUK PENULISAN ARTIKEL

Smith, Huston, Agama-Agama Manusia, terj. Safroedin Bahar,Jakarta: Yayasan Obor, 2001.

Swinton, John dan Harriet Mowat, Practical Theology and Qualitative Research, London: SCM Press, 2006.

Syamsuddin, Din, "Information Minded", dalam Suara Muhammadiyah, No. 06 TH Ke 99, 16-31 Maret 2014.

Taftāzānī, Abū al-Wafā al-Ghanīmī, Dirāsāt fi al-Falsafah al-Islāmiyah, Kairo: Maktab al-Qāhirah al-Ḥadīsah, I, 1957.

Tobroni, "Rekontruksi Pembelajaran AIK di PTM" dalam Suara Muhammadiyah, No. 06 TH Ke 99, 16-31 Maret 2014. 